\title{
Characterization of sedimentary depositional environments for land use and urban planning in Espoo, Finland
}

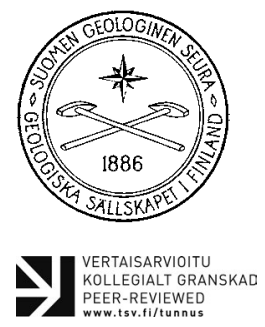

\author{
Maarit Saresma $^{\mathrm{I}^{*}}$, Emilia Kosonen ${ }^{\mathrm{I}}$, Antti E. K. Ojala ${ }^{\mathrm{I}, 2}$, \\ Anu Kaskela ${ }^{\mathrm{I}}$ and Leena Korkiala-Tanttu ${ }^{3}$ \\ ${ }^{1}$ Geological Survey of Finland, Vuorimiehentie 5, FI-02151, Espoo, Finland \\ ${ }^{2}$ Department of Geography and Geology, University of Turku, Akatemiankatu 1, \\ FI-20014, Turku, Finland \\ ${ }^{3}$ Department of Civil Engineering, Aalto University, Rakentajanaukio $4 \mathrm{~A}$, \\ FI-02150, Espoo, Finland
}

\section{Abstract}

The capital region of Finland is growing rapidly and into areas with challenging construction conditions such as deep fine-grained sediments. In the coastal city of Espoo, present land use is mainly focused in the southern and central parts, which were submerged by the Baltic Sea during the early and mid-Holocene. These areas have experienced saline and brackish water phases during the history of the Baltic Sea Basin. The deposition environments of the presently studied onshore areas are an analogue for the present day offshore Baltic Sea sedimentation settings for fine-grained material. The results from Baltic Sea studies have demonstrated that the seabed topography has a significant role in the deposition of sediments and their properties. In this study, paleotopographic models were created for the ancient Baltic Sea Basin in the Espoo area 1) after deglaciation and 2) during the Litorina transgression and classified into bathymetric (terrain) zones and structures. Topographic classification was combined with the water depth of the Litorina stage, the thickness of fine-grained deposits and wind fetch to establish the overall characteristics of sedimentary environments in the coastal area. Fine-grained sediments can be found mainly in depressions that are classified here as broad, narrow or local. The study found the most challenging environments for construction purposes in sheltered narrow depressions that contain thick layers of fine-grained sediments deposited during the Litorina transgression. These are mainly located in the southern and central parts of Espoo. Minor deep canyons were also found in the northern parts of Espoo. This study provides new prior knowledge for urban planning and construction design in Espoo. The methodology could be applied to other Baltic Sea coastal cities and areas with fine-grained sediments.

Keywords: Paleotopographic classification, fine-grained sediments, depositional environments, Benthic Terrain Modeler (BTM), wind fetch, land use, Espoo, Finland

*Corresponding author (e-mail: maarit.saresma@gtk.f) 


\section{Introduction}

The capital region of Finland is rapidly growing and there is a need to enhance land use planning and sustainable construction (Statistics Finland, 2014; Helsinki-Uusimaa Regional Council, 2019). In the city of Espoo, land use and urban planning are active in several districts, especially in connection with the development of transport systems (City of Espoo, 2018). In some of these areas, the construction conditions are challenging due to deep basins filled with fine-grained sediments. Understanding the overall distribution and characteristics of fine-grained sediments is necessary for geotechnical design and environmental issues. Each geotechnical design project includes ground investigations, but uncertainty is always present in the interpretation of the results. Sediment characteristics may be specified with probabilistic approaches such as reliability analyses (KorkialaTanttu \& Löfman, 2016; Löfman, 2016) expanded to geological sediment layers (Löfman \& KorkialaTanttu, 2019). Effectively, the reliability of the preliminary geotechnical design can be increased if the sediment characteristics are known. In addition to the environmental threat related to acid sulphate soil, awareness of its role in the formation of corrosion in thick fine-grained sediments has increased in geotechnical design (Suikkanen et al., 2018). Environmental issues also include urban flood management, where the location, structure and properties of fine-grained sediments are relevant (Nuottimäki \& Jarva, 2015).

The deposition of fine-grained sediments in southern Finland began after deglaciation at around 13000 years ago. The sedimentation processes, including saline and brackish water phases, have affected the structure and composition of these sediments (e.g. Gardemeister, 1975; Björck, 1995). The same physical and chemical conditions that affected sedimentation in southern Finland during the history of the Baltic Sea Basin (BSB) have also shaped the structure of the present offshore Baltic seabed, which contains several geomorphologically distinct sub-basins (Henriksson \& Myllyvirta, 2006; Kaskela, 2017; Virtanen et al., 2019). However, the role of geomorphology in the deposition and distribution of onshore fine-grained sediments has been less studied. The properties of fine-grained sediments vary regionally and are highly dependent on the geological environment, such as the topography of the basin, elevation level (metres above sea level, a.s.l.), location, thickness of the fine-grained material and hypoxic/oxic conditions during deposition. This study analysed the deposition environments of fine-grained sediments in the city of Espoo with geospatial methods, focusing on their thickness and spatial variability and the paleotopography of the BSB. The study aimed to identify different types of sedimentary environments in order to increase prior knowledge in assessing sediment characteristics for land use and construction design.

\section{Research materials}

\subsection{Study area}

\subsubsection{Geological characteristics}

The City of Espoo is located in southern Finland in the coastal area of the Baltic Sea. The town of Kauniainen is situated inside Espoo and is hence included in the study area. The topography and distribution of Quaternary superficial deposits in Espoo is determined by distribution of bedrock types and weakness zones. The large-scale NE-SW Porkkala-Mäntsälä fault zone separates the bedrock into granite, Bodom granite and granodiorite in the northern parts and metamorphic rock types (mostly quartz-feldspar gneiss, quartz diorite or granodiorite, mica gneiss, amphibolite and hornblende gneiss) and granite in the south (Härme, 1969; Laitala, 1960; Laitala, 1967; Laitala, 1994) (Fig. 1). 

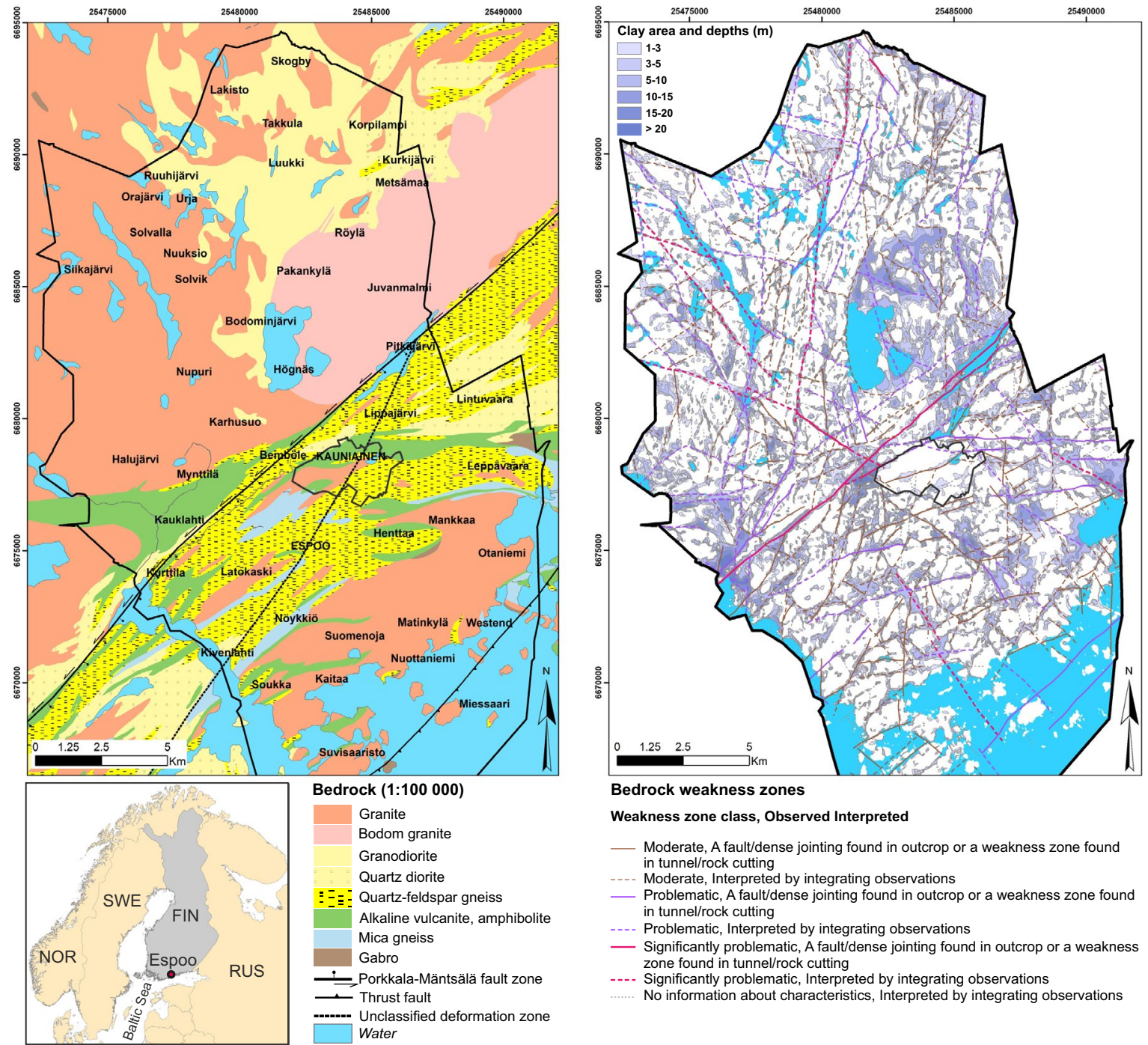

Bedrock weakness zones

Weakness zone class, Observed Interpreted

- Moderate, A fault/dense jointing found in outcrop or a weakness zone found in tunnel/rock cutting

---- Moderate, Interpreted by integrating observations

— Problematic, A fault/dense jointing found in outcrop or a weakness zone found in tunnel/rock cutting

--- Problematic, Interpreted by integrating observation

- Significantly problematic, A fault/dense jointing found in outcrop or a weakness zone found in tunnel/rock cutting

Significantly problematic, Interpreted by integrating observations

No information about characteristics, Interpreted by integrating observations

Figure 1. Bedrock (1:100000) map, bedrock weakness zones and clay depths of the study area and the location of the (NE-SW) Porkkala-Mäntsälä fault zone. The area in the middle surrounded by Espoo is the town of Kauniainen. Index map of the study location Espoo, Finland. Bedrock map 1:100000; Bedrock weakness zones; Clay areas and depths (C) Geological Survey of Finland.

The geological characteristics of the area reflect the post-glacial evolution of marine and lacustrine environments. The Quaternary superficial deposits have been reshaped and redeposited since deglaciation by erosional processes (land uplift and sea level changes) during marine and coastal stages (Repo et al., 1970; Haavisto \& Kukkonen, 1975), and the area is characterized by washed rocky hills and flat fine-grained basins (Fig. 2). The rocky hills are often surrounded by shore deposits and washed till, which lack the original moraine forms. Smallsized sorted coarse-grained deposits can typically be found on the leeside of the rocky hills (Repo et al., 1970). Some of the sorted coarse-grained sediments are possibly overlain by younger finegrained sediments, which have filled the bedrock depressions in the bedrock weakness zones (Fig. 1). 


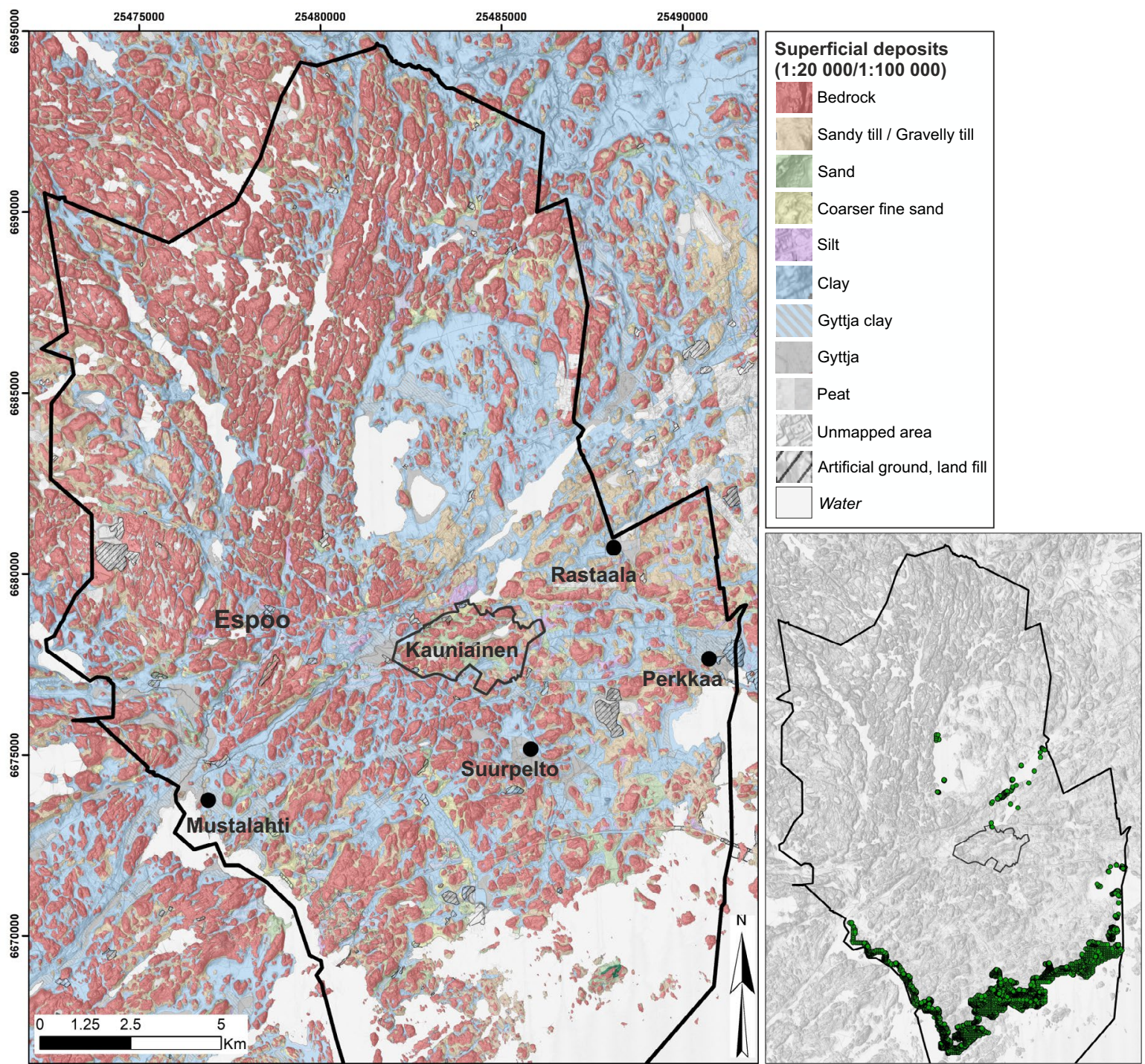

Figure 2. Quaternary superficial deposits map (1:20000/1:100000) of the study area with locations of clay stratigraphic study sites in Espoo (Ojala, 2007, 2009; Ojala et al., 2007) and additional geotechnical investigations within lake and shoreline areas. Quaternary superficial deposits 1:20000/1:100 000, MDHS @ Geological Survey of Finland.

Following the last deglaciation, the history of the BSB has traditionally been divided into phases known as the Baltic Ice Lake, the Yoldia Sea, the Ancylus Lake and the Litorina Sea (Björck, 1995; Andren et al., 2000). Due to isostatic rebound and eustatic sea-level changes, the Baltic Ice Lake and the Ancylus Lake were freshwater basins. In part, the Yoldia Sea and more saline Litorina Sea were brackish according to diatom data and organic productivity (Andren et al., 2000). During post- glacial evolution, mainly fine-grained sedimentary material was deposited in an aquatic environment, covering the uneven bottom. These fine-grained sediments filled the depressions shaped by bedrock weakness zones and formed sedimentary deposit plains that are presently located above the Baltic Sea level. The average thickness of these fine-grained deposits in southern Finland is ca. 10 metres (Gardemeister, 1975). 
The structure and properties of fine-grained sediments vary according to prevailing environmental conditions when deposition occurred. These conditions include the water depth, wave action and bottom currents, the amount of suspended material, water stratification, salinity, chemistry, redeposition and organic production (Gardemeister, 1975; Ojala, 2007). The postglacial fine-grained sediments deposited during the Baltic Ice Lake stage consist of massive grey, sometimes reddish-coloured clay with a varved structure and anisotropic character (Gardemeister, 1975; Ojala et al., 2007; Ojala, 2007; Haavisto \& Kukkonen, 1975). These sediments contain sand and silt layers and they have the lowest water and humus content of the sediments deposited during BSB history. Yoldia sediments are usually laminated or homogeneous in structure, with clayey material in the largest amounts (Gardemeister, 1975). The classification properties of the sediments deposited during the Ancylus Lake stage show no significant difference from the lower Yoldia sediments. Younger Ancylus sediments generally contain more water and humus than the underlying deposits. Ancylus sediments often contain silty and sandy layers caused by erosion and re-deposition over time as the water level has rapidly changed. Sulphide grains and nodules are sometimes seen in clay deposited during the Ancylus stage (Gardemeister, 1975; Ojala et al., 2007; Ojala, 2007; Ojala, 2009; Kosonen et al., 2015; Saresma et al., 2017).

\subsubsection{Litorina sediments}

The sediments deposited during the Litorina Sea stage differ significantly from the other sediments of the BSB and are sometimes separated from the underlying deposits by an erosional surface (unconformity) (Ojala et al., 2018). Typical features of Litorina sediments include high water and organic contents and, according to Gardemeister (1975), often an appreciably greater plasticity index and liquid limit compared to other sediments of the BSB. These Litorina sediments are usually very compressive and weak in strength. Litorina sediments contain the maximum pore water salinity, which may lead to a high void ratio associated with the high water content (Gardemeister, 1975; Mataic, 2016). This usually indicates increased compressibility of the sediment layer. Pore water salinity and the high void ratio can also expose the sediment to leaching, leading to high sensitivity and low stability (Bjerrum, 1967; Helenelund, 1977; Mataic, 2016). In addition, some sediments contain sulphide due to the high organic productivity and hypoxic conditions during the Litorina Sea stage (Boman et al., 2008; Suikkanen et al., 2018). Finally, the bottom topography during the Litorina Sea transgression has an important role in predicting potential areas for sulphide formation and soft sediment deposition. Topographically sheltered deep sub-basins of the BSB often develop hypoxia, as they are not subject to wave action or bottom currents (Virtasalo et al., 2005; Kaskela, 2017; Jokinen et al., 2018; Virtanen et al., 2019). Instead, they exhibit strong water stratification and a limited water exchange that exposes them to sulphide formation.

\subsection{Datasets}

The Geological Survey of Finland has combined and unified a "Clay area and depth" dataset (Geological Survey of Finland, HAKKU) for the Helsinki Metropolitan Area (the cities of Helsinki, Espoo and Vantaa) (Kosonen \& Saresma, 2020). This dataset is based on soil maps (1:10000-1:2000) of the three cities, which contain interpolated clay depth contours $(1,3,5,10,15$ and $20 \mathrm{~m})$ based on geotechnical investigations. The clay depth is the depth (metres from the terrain surface) of cohesive soft fine-grained sediments. In addition, over 3000 geotechnical investigations (Swedish Weight Soundings) within areas without contour depth data (lake and shoreline areas) (Fig. 2) as well as gyttja sediment (1-3 m, >3 m) polygons were available for this study from the City of Espoo. This study also utilized geological maps of Quaternary superficial deposits (1:20 000; 1:100 000) (Geological Survey of Finland, HAKKU), airborne scanning 
light detection and ranging (LiDAR) data, a digital elevation model (DEM), cloud point data (National Land Survey of Finland) and MDHS (multidirectional hillshade) data processed from LiDAR DEMs by the Geological Survey of Finland with ArcGIS (CESRI) software. Åberg (2013) and Ojala et al. (2013) have reconstructed the maximum extension and highest shoreline elevation of the Litorina Sea transgression (Ancient Shoreline Database) (Geological Survey of Finland, HAKKU), which was utilized in the paleotopographic and paleobathymetric model of the Litorina transgression stage. All datasets were projected to the ETRS-GK25 coordinate system used by the cities of the Helsinki metropolitan area.

\section{Methods}

\subsection{Paleotopographic models}

In addition to the current terrain surface, two additional sets of paleotopographic elevation models were created in the ArcGIS environment $\left({ }^{\circledR} \mathrm{ESRI}\right)$ to simulate the terrain surface level and environmental conditions 1) after deglaciation (DG), when fine-grained material began to deposit during the Baltic Ice Lake stage, and 2) at the beginning of the Litorina transgression (LT) stage, ca. 7000 years BP (before present) (Hyvärinen et al., 1999) (shoreline 32-35 $\mathrm{m}$ a.s.l. in the Espoo area) (Ojala et al., 2013), when approximately twothirds of the total thickness of fine-grained sediment had been deposited (Fig. 3). This estimation of clay accumulation is based on observations from stratigraphic studies in the clay basins of Espoo, i.e. Suurpelto (Ojala et al., 2007), Äijänpelto (Ojala, 2007), Mustalahti and Perkkaa (Ojala, 2009) by GTK (Fig. 2) that show similarity with other stratigraphic studies in the near coastal area of southern Finland (e.g. Gardemeister 1975). The topmost third of the deposition contains organicrich fine-grained sediments (gyttja clay, clay gyttja and post-isolation lake gyttja) accumulated during and after the Litorina transgression.
In order to create continuous paleotopographic models, interpretations of geotechnical investigations and lake and seawater depth points (National Land Survey of Finland) were used to interpolate depth contours also to lake areas as well as beyond shoreline and municipal borders (Fig. 5a). Lake water depth contours have been shown to reflect the post-glacial soft sediment thickness in lakes (Valpola \& Ojala, 2006). Overall, the analysis area was selected to be larger than the municipal borders of Espoo (Fig. 5a) so that possible biases in margin areas would not affect the results for the selected study area (Mäkiaho, 2009).

This unified clay depth dataset was used to create a combined and congruent model of the finegrained glaciomarine and -lacustrine deposits in Espoo area for further spatial data analysis (Fig. 5a). The clay depth raster (depth $\mathrm{m}$ ) was interpolated from depth contours with the ArcMap "Topo to raster" tool (ArcGIS Desktop 10.6), which is designed to create hydrologically correct digital elevation models (Hutchinson et al., 2011) and is suitable for contour data interpolation. "No Enforce" setting was used to avoid sinks to be filled. Interpolation was made in a $10 \mathrm{~m}$ cell size that was considered suitable for an area this wide, with the dataset available and taking into account the stratigraphically well-studied sites. The LiDAR $\operatorname{DEM}(10 \mathrm{~m})$ was converted to a digital terrain model (DTM) by removing the artificial elevation changes ( $>3 \mathrm{~m}$ ) (high buildings, roads, landfill areas) to match the original elevation of the prevailing clay basin (Mäkiaho, 2009). Old maps were used to verify the original elevation (National Land Survey, 1958a; 1958b; 1960; 1961). In the next phase, the clay depth raster was reduced from the modified DTM $(10 \mathrm{~m})$ elevation raster to create a realistic continuous paleotopographic elevation model ( $\mathrm{m}$ a.s.l.) for the bottom layer of the finegrained sediments (Fig. 3). The thickness of overlying water (lake, sea) and peat were reduced from the total thickness to obtain the thickness of fine-grained sediments (Rosentau et al., 2007). For the paleotopographic model of the Litorina transgression, two-thirds of the soft sediment 


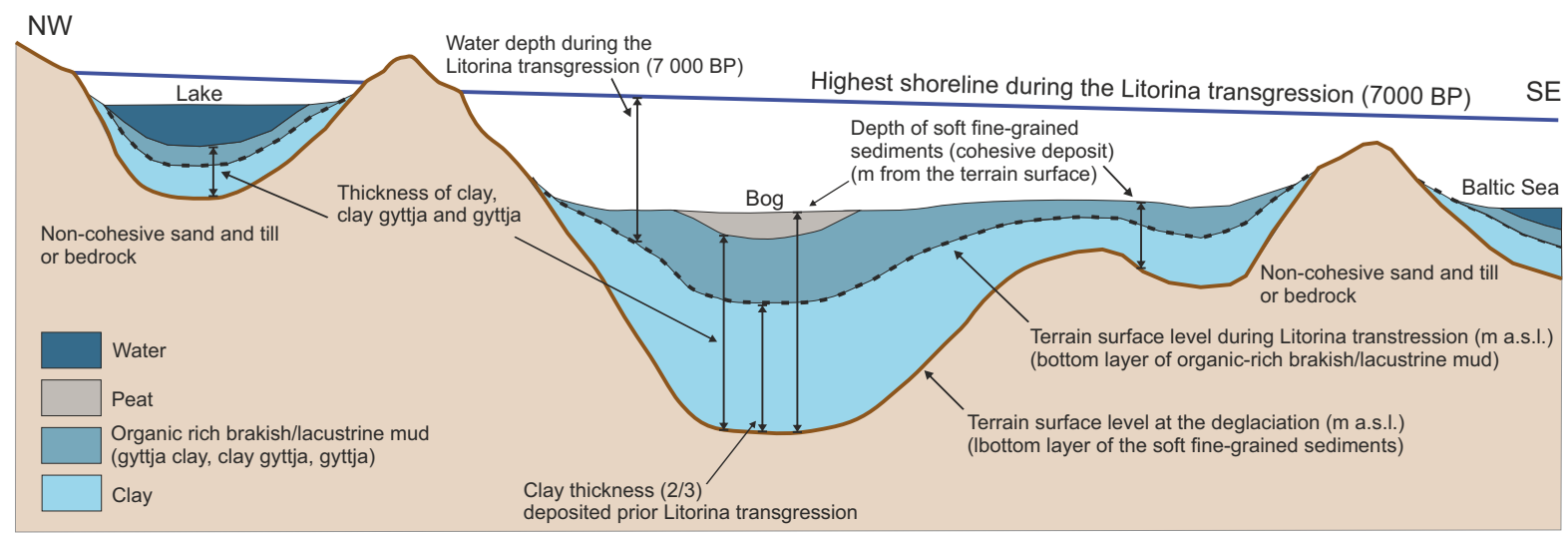

Figure 3. Conceptual model of the paleotopographic terrain surface levels in the Espoo area, the fine-grained sedimentary environments and water depth during the Litorina transgression.

thickness was added to the bottom of the finegrained sediments to simulate the paleotopographic elevation ca. 7000 years BP (Fig. 3).

\subsection{Benthic Terrain Modeler (BTM)}

Benthic Terrain Modeler (BTM) (Walbridge et al., 2018), built on top of the ArcGIS platform, was used to characterize and classify the underwater paleotopography of the BSB 1) after deglaciation and 2) during the Litorina transgression in the Espoo area. BTM is traditionally a marine tool that calculates topographically different landforms based on bathymetry, slope and the bathymetric position index (BPI), which is a marine modification of the topographic position index (TPI) (Weiss, 2001; Lundblad, 2006).

Slope, as the first-order derivative, was calculated with the ArcGIS surface analysis tool. The resulting raster grid shows the maximum rate of change between each cell and its eight neighbours. Slope data were classified into three classes, $<5 \%, 5-10 \%$ and $>10 \%$ according to the approximate mean steepness of the study area in the 1) DG stage. This classification was chosen to best represent the initial stage and its change to 2) LT stage. The second-order derivative BPI quantifies topographic crests and depressions by comparing the elevation of a cell with the mean elevation othe neighbourhood cells within a specified radius and produces positive (crests) and negative (depressions) BPI values, in addition to values near zero that represent flat areas or areas of constant slope (Walbridge, 2018). Several BPI surfaces with varying radiuses were tested to find the best representation of the different geomorphological features. Fine-scale BPI ${ }_{700 \mathrm{~m}}$ and broad-scale $\mathrm{BPI}_{2 \mathrm{~km}}$ proved to be the best fit to emphasize the bottom structures, as evaluated at the well-studied sites of Suurpelto (Ojala et al., 2007; Pätsi, 2009), Äijänpelto (Ojala, 2007), Mustalahti and Perkkaa (Ojala, 2009) (Fig. 6). The standardized BPI values together with paleotopographic elevation models and slope were further classified into zones called crests, depressions, flat areas and slopes, as well as structures modified after Lundblad et al. (2006), Erdey-Heydorn (2008), Kaskela et al. (2012), Rinne et al. (2014) and Walbridge et al. (2018) (Fig. 4 and Table 1).

\subsection{Litorina water depth and wind fetch model}

A wind fetch model was used to test the effect of wind and wind fetch on the ancient Espoo coastal area during the Litorina stage (from transgression $7000 \mathrm{BP}$ to $4000 \mathrm{BP})$. This analysis used the wind fetch model of Rohweder et al. (2012) generated for the ArcGIS environment by the USGS. For the Litorina transgression environment, the 
Figure 4. A flowchart showing the steps in Benthic Terrain Modeler BTM. In the Espoo area paleotopography classification was produced with BTM based on paleotopography models, broad Benthic Position Index BPI, fine BPI and slope. Classification included four zones and eight structures in the Espoo study area.

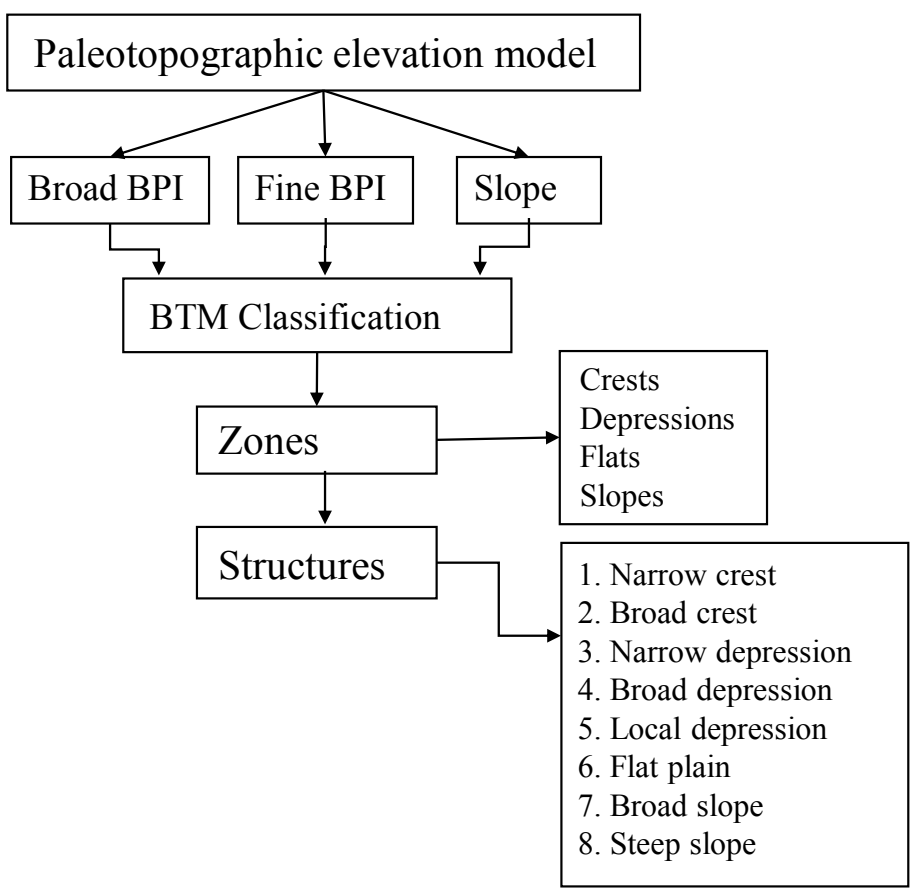

Table 1. BTM structure catalogue; “100” refers to one standard deviation of the standardized BPI.

\begin{tabular}{|c|c|c|c|c|c|c|c|}
\hline \multirow[b]{2}{*}{ Class } & \multirow{2}{*}{$\begin{array}{l}\text { Classification } \\
\text { Structure }\end{array}$} & \multicolumn{2}{|c|}{ Broad scale BPI } & \multicolumn{2}{|c|}{ Fine scale BPI } & \multicolumn{2}{|c|}{ Slope } \\
\hline & & Lower & Upper & Lower & Upper & Lower & Upper \\
\hline 1 & Narrow crest & 100 & & 100 & & & \\
\hline 2 & Broad crest & 100 & & -100 & 100 & & \\
\hline 3 & Narrow depression & & -100 & & -100 & & \\
\hline 4 & Broad depression & & -100 & -100 & 100 & & \\
\hline 5 & Local depression & -100 & 100 & & -100 & & \\
\hline 6 & Flat plain & -100 & 100 & -100 & 100 & & 5 \\
\hline 7 & Broad slope & -100 & 100 & -100 & 100 & 5 & 10 \\
\hline 8 & Steep slope & -100 & 100 & -100 & 100 & 10 & \\
\hline
\end{tabular}

Litorina shoreline data of Ojala et al. (2013) were used to create land (1) and water (0) areas. The Litorina L30 and L40 isobases (polylines) of Ojala et al. (2013) were used to create an interpolated isobase surface (raster), i.e. Litorina water plane. A water depth model (paleobathymetry) of the Litorina transgression (Fig. 3) was constructed by subtracting the Litorina water plane values from the LT paleotopographic raster (Leverington et al., 2002). A new shoreline model was created for the
$4000 \mathrm{BP}$ environment by using the L30 and L35 isobase shore displacement curves and gradient/ time curve $(\mathrm{cm} / \mathrm{km})$ for the Helsinki Metropolitan Area (Hyvärinen, 1999; Seppä et al., 2000; Leverington et al., 2002; Mäkiaho, 2009). The 4000 $\mathrm{BP}$ water plane values were subtracted from the paleotopographic elevation raster simulating the environment 4000 years BP, where four-fifths of the soft sediment thickness (Ojala, 2007, 2009; Ojala et al., 2007) was added to the clay basin subsurface. 


\subsection{Statistical comparison}

Statistical comparisons were used to assess the environmental variables associated with topographic depressions during the Litorina transgression. The amount of depressions, their average area and statistics related to clay thickness were calculated using ArcMap "Zonal statistics" tool. It calculates statistics on cell values of a raster (here clay thickness raster) within the zones defined by another dataset (here topographic depressions). Additionally, mean, maximum and minimum elevation ( $\mathrm{m}$ a.s.l.) and Litorina stage water depth were calculated with "Zonal statistics" for narrow depressions to find out if these variables are related with each other and clay thickness. The length of the shortest and longest axis was calculated with the Arcmap "Zonal geometry" tool. The tool calculates a specified geometry measure for every zone in a dataset (here topographic depressions). Multivariate clustering in the ArcGIS Pro environment was used to explore the underlying structures of the data and spatial comparison of the environmental attributes in the focus area of this study, narrow depressions. Several possible combinations of features with different amounts of clusters were tested with K-Means algorithm. Although sometimes sensitive to outliers, K-Means algorithm tends to find natural patterns in the data and can be used here for statistical comparison among environmental variables. In this study, four clusters proved to best represent both within-group similarities and between-group differences.

\section{Results and interpretation}

\subsection{Paleotopographic models}

The depth of fine-grained sediments in the study area, including land, lake and sea areas ( $\mathrm{m}$ from the terrain surface), varies between 0-35 metres (Fig. 5a). The thickness of the fine-grained sediments varies between 1-25 metres, with the thickest clay deposits in the Mustalahti, Suur- pelto, Kirkkojärvi and Espoonlahti areas. The paleotopographic elevation level after deglaciation varied in the whole study area between -29-117 m a.s.l., and in clay basin areas between -29-103 $\mathrm{m}$ a.s.l. (Fig. 5b). During the Litorina transgression stage, the paleotopographic elevation level varied between -15-117 m a.s.l., and in clay basin areas, situated below the highest shoreline area, between -15-36 m a.s.1. (Fig. 5c).

\subsection{Benthic Terrain Modeler (BTM)}

The landscape of the ancient underwater Espoo was topographically diverse 1) after deglaciation (Figs 6a, 6b, 6c and 7). Steep slopes dominated the landscape and mainly divided it into crests leading down to different depressions (Fig. 7). Most of the narrow depressions were canyon-shaped structures that formed in bedrock weakness zones and faults after deglaciation. Fine-grained material began to deposit in the deepest depressions and smoothed the topography. At the beginning of the Litorina transgression (2), the deepest canyons were filled with silts and dense clay and the landscape was flatter (Figs 6d, 6e, 6f and 7). The northern parts of Espoo were mainly unsubmerged, and fine-grained organic-rich material began to deposit in the lowlying parts of southern and central Espoo. The topography consisted of crests, depressions, flat plains and slopes with relatively low gradients. The depressions further divided into narrow depressions and broad and local depressions. At 2) LT stage narrow depressions appeared mostly canyonshaped long structures but also as individual isolated structures that usually are basins with various shapes including circular shape. In addition to narrow depressions, broad and local depressions occurred in the seabed. Broad depressions represented wide basins usually attached to narrow depressions. Small-scale local depressions occurred individually around Espoo, mainly focused in the southern parts of the region. 

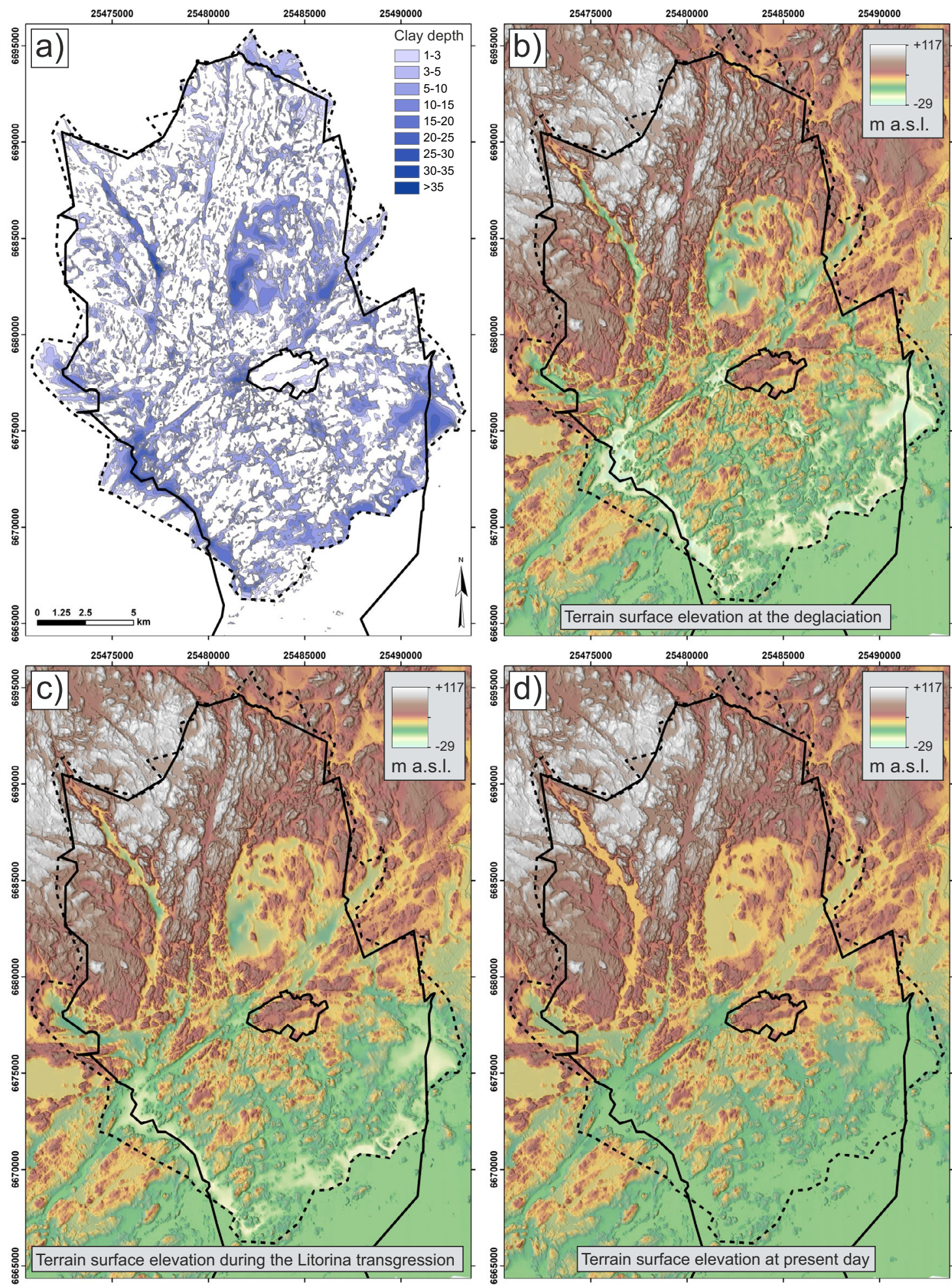

Figure 5. The unified and extended clay depth areas (a), two different sets of paleotopographic models (b, c) and the present day topographic elevation map (d). Elevation scales are set for all stages (b-d) according to the max-min elevation in the deglaciation stage. The municipal border of Espoo is indicated with a solid line and the extended study area with a dashed line. The area in the middle surrounded by Espoo is the town of Kauniainen. 

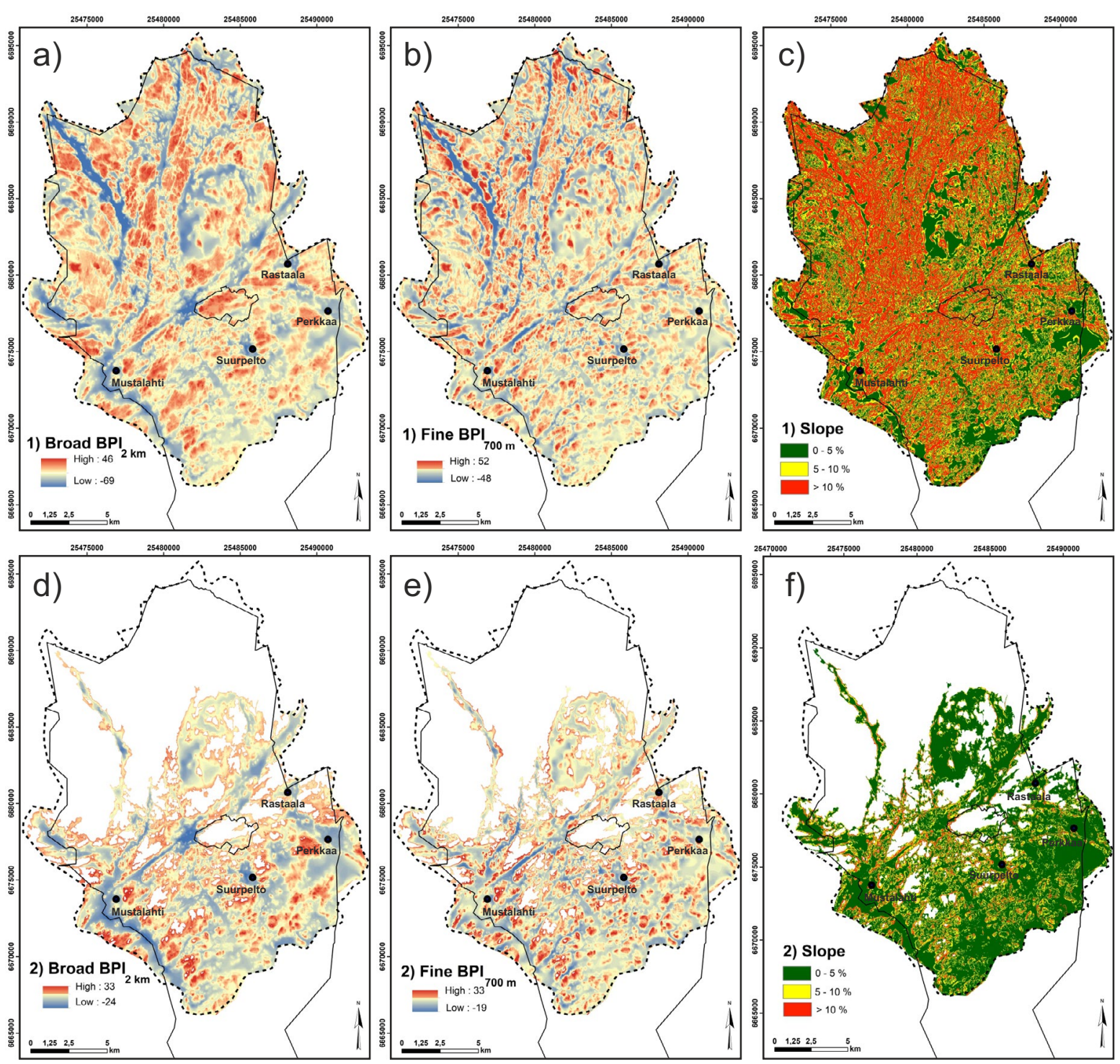

Figure 6. BPI values together with slope form the basis for the topographic classification 1$)$ after deglaciation $(a, b, c)$ and 2) during the Litorina transgression (d, e, f), when the northern parts and highest hills of Espoo and Kauniainen were above sea level. Negative BPI values indicate depressions and high values are elevations. Locations of clay stratigraphic study sites in Espoo (Ojala, 2007, 2009; Ojala et al., 2007) are indicated and the extended study area marked as dashed line. The municipal border of Espoo is indicated with a solid line and the area in the middle surrounded by Espoo is the town of Kauniainen. 

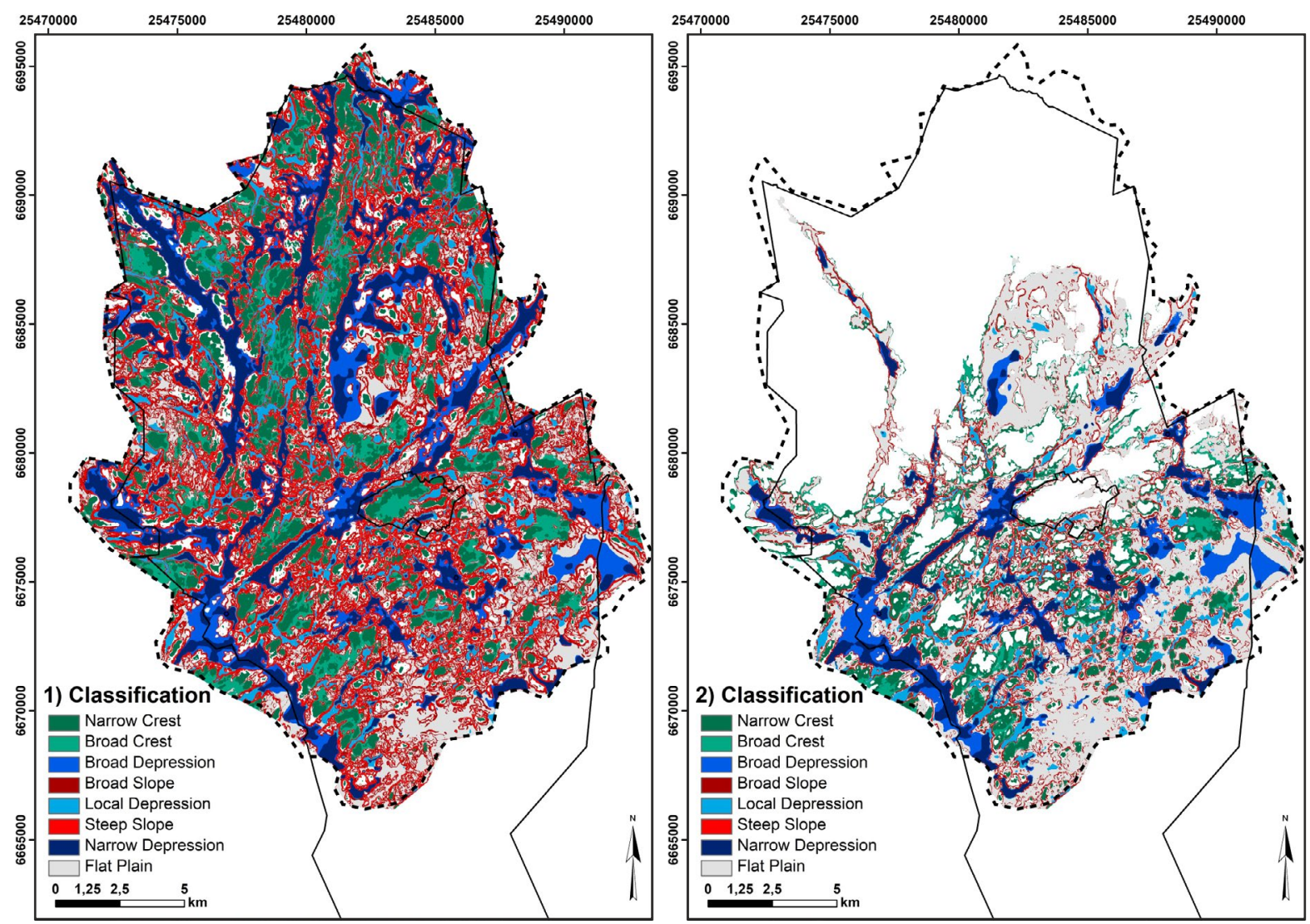

Figure 7. Topographic classification 1) after deglaciation and 2) during the Litorina transgression, when the northern parts and highest hills of Espoo and most of Kauniainen were already above sea level. The municipal border of Espoo is indicated with a solid line, extended study area with dashed line and the area in the middle surrounded by Espoo is the town of Kauniainen.

\subsection{Litorina water depth and wind fetch model}

Virtanen et al. (2019) demonstrated that wave action or the lack of it is a significant factor in the development of severe hypoxia in coastal areas. A study of eutrophication risks in the Finnish coastal area by Henriksson and Myllyvirta (2006) indicated that water depth and geomorphologic landform types affect the development of hypoxic conditions. In the Litorina stage, most parts of northern and northwestern Espoo were dry land near the coast (Fig. 8). Between north and central Espoo, a sheltered archipelago existed with mostly shallow water depths $(0-20 \mathrm{~m})$ and a few deeper $(>30 \mathrm{~m})$ canyons, which are also presently dry lake basins.
According to Henriksson and Myllyvirta (2006), hypoxic conditions in shallow water archipelago environments were associated with depths of over $10 \mathrm{~m}$. Northern Espoo was mainly sheltered with short wind fetch distances, but a few wide areas, for example the Bodom lake area, experienced more effective wind fetch exposure. In the central parts of Espoo, the water deepened, with an average depth of over 20 metres and larger canyon areas with depths of over $30 \mathrm{~m}$. The central area of Espoo comprised more open wind-prone areas with larger wind fetch exposures. However, sheltered areas also existed that experienced minor wind fetch exposures. The southern and southeastern parts were deep-water areas with water depths mainly exceeding $30 \mathrm{~m}$. This area experienced open-water 
conditions during the Litorina stage, with long wind fetch distances and greater effective exposure (Fig. 8). For hypoxic conditions to develop in deep water areas, a water depth of more than $30 \mathrm{~m}$ was needed in geomorphological sheltered depressions and craters (Henriksson \& Myllyvirta, 2006). Therefore, mixing of bottom water in deep (over 30 metres) depressions was not likely due to the water depth. At the end of the Litorina stage (4000 BP), the shoreline level was situated around $21-22 \mathrm{~m}$ a.s.l. in the Espoo area. The sheltered archipelago had shifted to central Espoo with shallow water depths $(0-20 \mathrm{~m})$. Open-water conditions still prevailed in southeast Espoo, with effective wind fetch exposures. The deepest water depths $(>20 \mathrm{~m})$ existed in narrow depressions of south Espoo and in the current coastal and sea areas. Due to waveinduced water mixing, wind fetch is one of the three factors together with wind speed and duration to affect the circulation and mixing of water. Without long wind fetch distances, changes in wind speed or duration do not lead to large waves and mixing, and all three factors are needed for large waves to occur (Duxbury et al., 2002).

Therefore, wind fetch analysis can provide an overview of the wind-driven water mixing areas that existed during the Litorina stage. With the combination of wind fetch and water depth values, the possible hypoxic areas conform with the classification results.

\subsection{Statistical comparison}

The main results from the zonal statistics are presented in Table 2. Of all the depressions in the
Espoo area that are formed during the Litorina transgression, narrow depressions with the largest average area were the least frequent. In these narrow depressions, the total average clay thickness is the highest and the standard deviation is the greatest. Broad and local depressions differ from each other mainly in their number and average area. Local depressions with the smallest area are the most common. They have also the lowest total clay thickness, although the difference between broad and local depressions is small.

Narrow depressions were further divided into four clusters that provided best both within-group similarities and between-group differences among selected variables: area, maximum clay thickness, maximum elevation, shape and maximum Litorina water depth (Figs 9 and 10). A south-north trend can be observed in the clustering results. The members of group 1 are mainly located in the southeast, group 3 in the north and groups 2 and 4 between the former two groups. Group 1 mostly consists of circular or various shapes of depressions that are located at a low elevation near the shoreline, where the water was deep in the Litorina stage. Only a few narrow depressions belong to group 2 , with a small area and elongated appearance. In group 2, the maximum clay thickness was lowest among the depressions. Group 3 in the north is high in elevation and low in Litorina water depth. This group contains thick clay deposits. Group 4 is distinguished from the others by large areas and the thickest clay deposits. Group 4 contains elongated canyon-like depressions with deep water in the Litorina stage.

Table 2. Comparison of clay thickness between narrow, broad and local depressions, in addition to their number and average area.

\begin{tabular}{lcccccc}
\hline & Count & Area average & Min clay thickness & Max clay thickness & Mean clay thickness & StDev \\
\hline \multirow{2}{*}{ Narrow depressions } & $(-)$ & $\left(\mathrm{m}^{2}\right)$ & $(\mathrm{m})$ & $(\mathrm{m})$ & $(\mathrm{m})$ & $(-)$ \\
Broad depressions & 248 & 84875 & b.d.l. & 25.0 & 8.0 & 4.0 \\
Local depressions & 473 & 30400 & b.d.l. & 24.5 & 6.0 & 3.5 \\
\hline
\end{tabular}



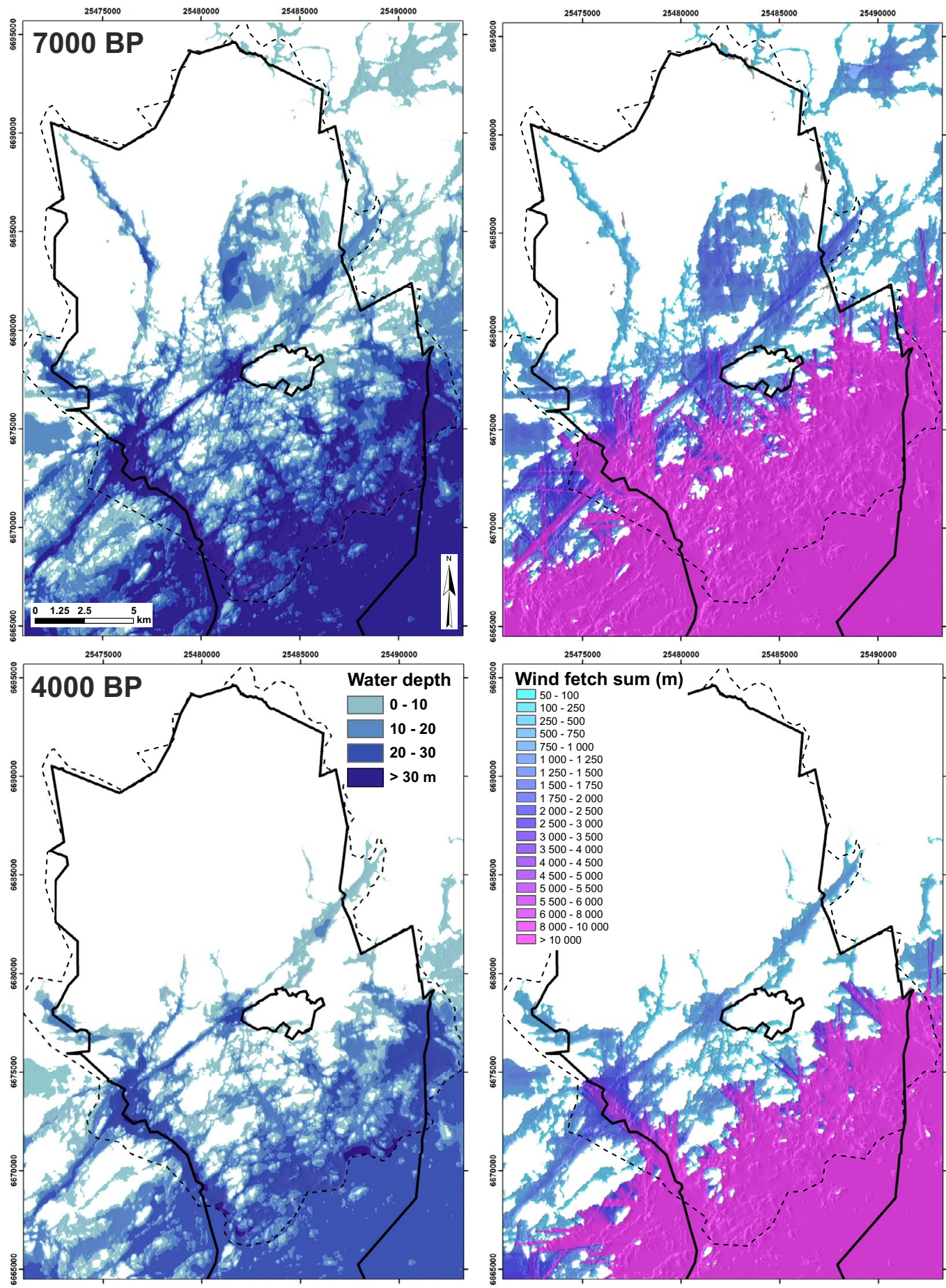

Figure 8. Water depth and wind fetch sum values calculated from weighted fetches in eight directions during the Litorina transgression (7000 BP) and at the end of the Litorina stage (4000 BP) in the Espoo area. The municipal border of Espoo is indicated with a solid line, extended study area with dashed line and the area in the middle surrounded by Espoo is the town of Kauniainen. 


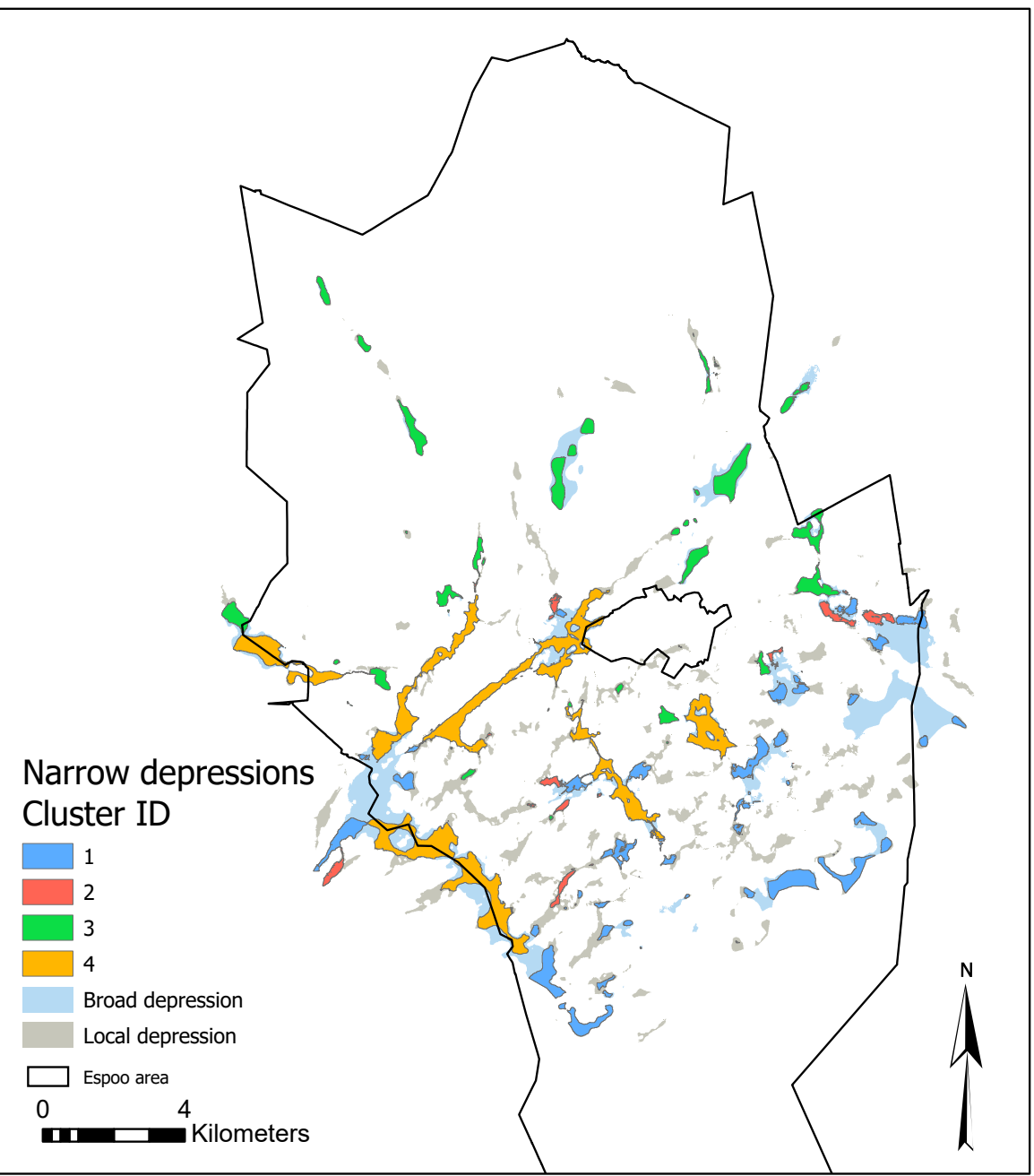

Figure 9. Narrow depressions were categorized into four clusters with a k-means algorithm. The municipal border of Espoo is indicated with a solid line and the area in the middle surrounded by Espoo is the town of Kauniainen.

\section{Multivariate Clustering Box-Plots}

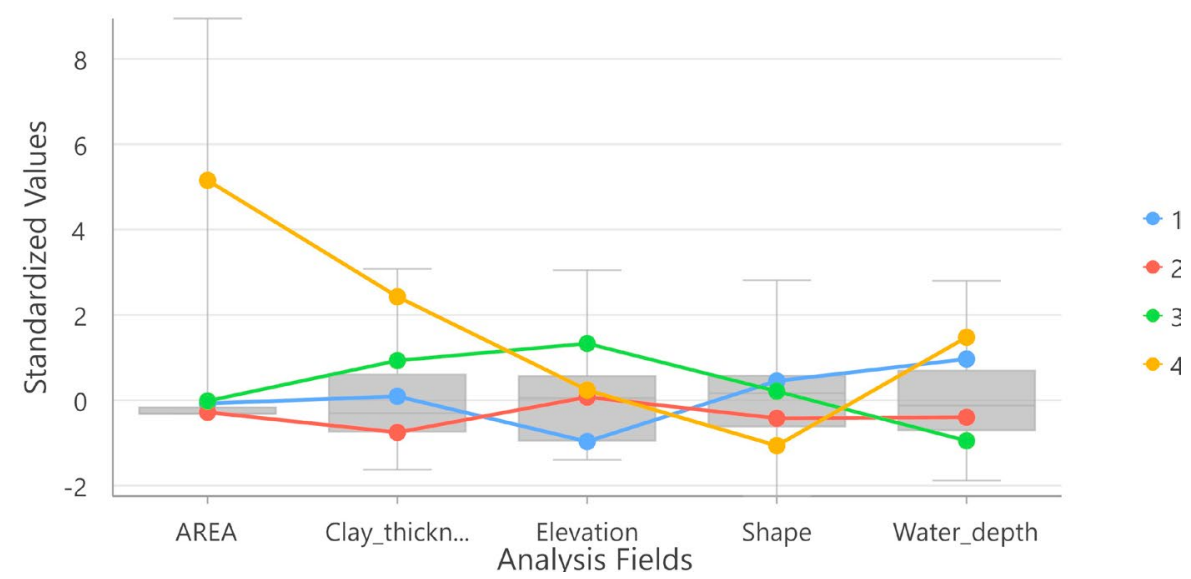

Figure 10. Distribution of area, maximum clay thickness, elevation, shape and maximum Litorina water depth in clusters. 


\section{Discussion}

The paleotopography of the Espoo area after deglaciation and its classification with Benthic Terrain Modeler revealed a number of high hills and low depressions. Most of the depressions were at that time located in bedrock weakness zones and fractures, which later filled with fine-grained sediments deposited during the Baltic Sea stages. A similar deposition succession has been reported several times in the offshore environment, for example, in the western part of the Gulf of Finland (Nuorteva, 1994). The paleotopographic model of the Litorina transgression stage revealed that the same narrow depressions that dominated the landscape after deglaciation were still present, but with a somewhat smoothed structure in the deepest canyons after filling with proglacial and distal fine-grained clayey sediments. One interesting characteristic of the study area is that narrow depressions indicated by the terrain analyses show also on average the thickest sections of fine-grained sediments (Table 2). This is considered to be due to their location, being sheltered by the surrounding high relief environment. Furthermore, Litorina water depth analysis supported the results of the topographic classification, as the areas with the greatest water depth $(>30 \mathrm{~m})$ in the southern parts of Espoo appeared to be connected with areas of narrow depressions. Wave action and strong winds blowing from the open sea in the south probably never disturbed the bottom in these depressions and the water remained stratified, allowing the development of hypoxic conditions. The importance of the sheltering effect in relation to seasonal seafloor hypoxia and the maintenance of a calm environment with continuous sediment accumulation has been discussed by Nuorteva (1994) and Virtanen et al. (2019), among others. According to Boman et al. $(2008,2010)$, a lack of oxygen combined with an abundance of FeS and $\mathrm{FeS}_{2}$ in the water column led to the formation of sulphide soil in the Litorina stage. In a recent study, Saresma et al. (2020) demonstrated a statistical association between narrow depressions and potential sulphide soil in the Espoo area. In addition to narrow depressions, which are often connected to broader basins, a somewhat different deposition environment is represented in small-scale local depressions. These individual depressions are scattered around the study area, but most of them occur in the southern parts of Espoo. They contain on average the thinnest layer of Litorina soft clay.

The regional remote-sensing-based spatial classification of different types of sedimentary environments in the Espoo area can be validated through local in situ sediment datasets, of which two examples are presented here. In the present topographic analyses, these two site-specific examples represent two different deposition environments of the Litorina stage: the Suurpelto area as a narrow depression and the Kallvik area as a local depression (Fig. 11).

Suurpelto is a well-known site in the capital region and has been stratigraphically investigated (Ojala et al., 2007; Ojala, 2011). The Suurpelto clay basin is surrounded by hills, which makes it a sheltered deposition environment. The fine-grained deposits reach up to $25 \mathrm{~m}$ in thickness in the deepest depressions of the basin. The Suurpelto fine-grained section comprises undisturbed in situ deposits representing the entire Baltic Sea basin history, including Litorina and post-Litorina sediments, which consist of very soft, highly organic-rich gyttja, and brackish water muds, which contain sulphidic sediments (Ojala et al., 2007). Here, the corrosion risk to underground piles and other structures was studied (Törnqvist \& Laaksonen, 2008), because several sulphide-containing soil layers were detected (red points in Fig. 11). Törnqvist \& Laaksonen (2008) concluded that the structures should be designed to tolerate a higher corrosion risk than normally. In addition, Pätsi (2009) examined the effect of organic material and sulphide from the viewpoint of deep stabilization and found that the shear strength of stabilized sulphide-containing layers did not develop as much as required (Pätsi, 2009).

The Kallvik area (Fig. 11), by comparison, is a very different deposition environment and was 


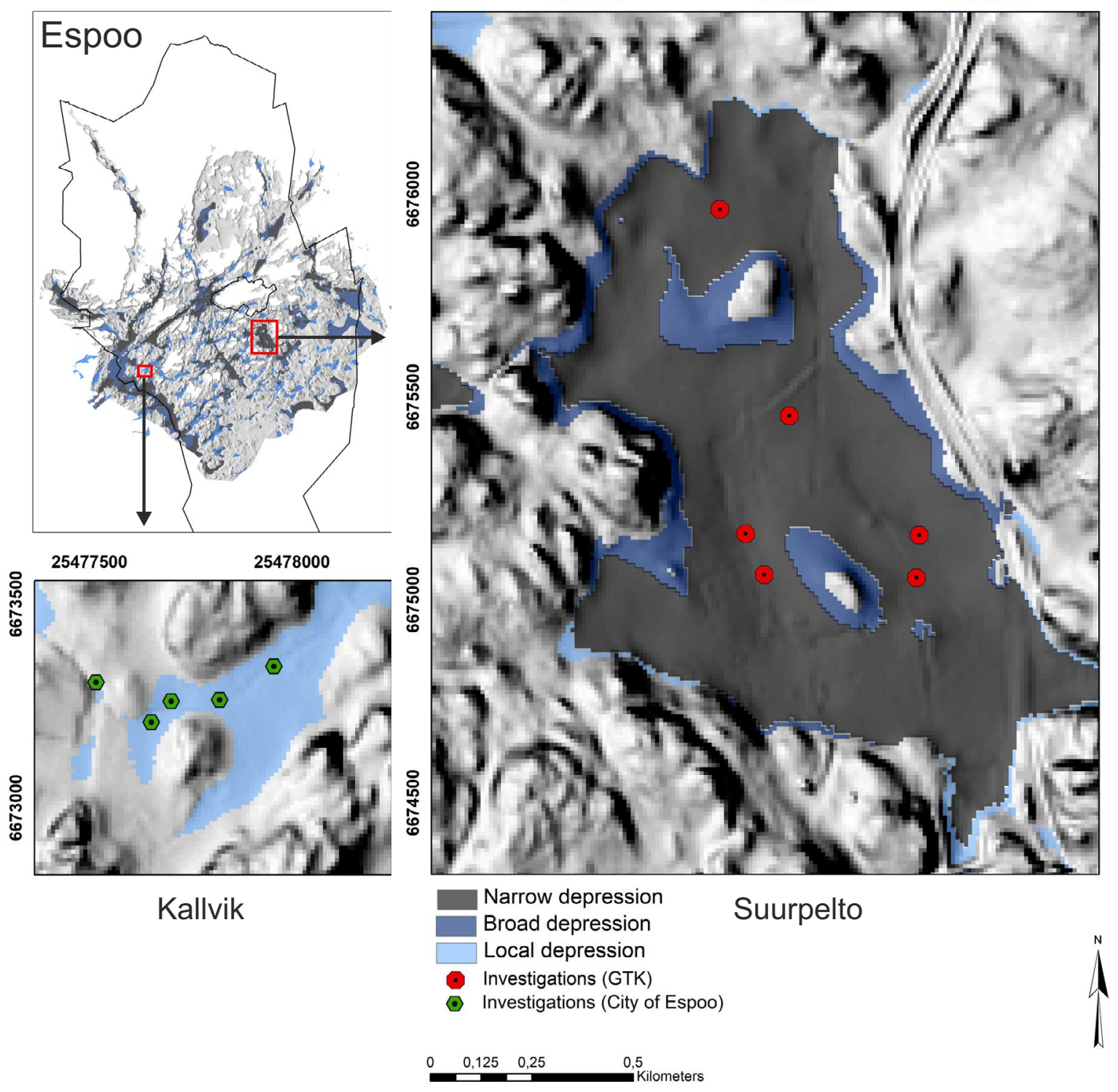

Figure 11. Illustrations of two different deposition environments during the Litorina transgression: the Suurpelto and Kallvik sites. Suurpelto represents a narrow depression and Kallvik a local depression. Investigations at Kallvik are presented here with permission from the City of Espoo. Some artificial elevation changes can be seen in the paleotopographic model, although they occur in areas outside the focus of this study.

chosen here to represent a local depression, since sulphide soil has also been investigated in the area in relation to construction. There are higher elevations and few hills in the surroundings of the Kallvik clay basin in the north and southeast, but the landscape is mostly even and free from wind fetch and wave motion, with a water depth of less than 30 metres
(Figs 8 and 11). According to earlier investigations, the soil at Kallvik is mainly gyttja clay with a depth of up to 2.5-3 metres (Ellonen \& Taipale, 2019). No notable sulphide soil has been observed there (Figure 11, green points).

Both Suurpelto and Kallvik were identified by the topographic model, and they both contain 
organic-rich sediments. Although gyttja, gyttja clay and clay gyttja are generally challenging from the perspective of construction, only Suurpelto contains sulphide. Furthermore, the sites differ from each other in the topographical environment and thickness of fine-grained sediments. A comparison of these two sites indicates that a sheltered environment with a certain amount of fine-grained, organic-rich sediments is needed for sulphide formation and deposition in Litorina sediments. However, this observation, which is based on results from two different sites, cannot be generalized to all clay basins in Espoo. Therefore, more site-specific studies are needed in the future. Nevertheless, the results from the topographic model are consistent with those from in situ investigations, which confirms the suitability of the model.

One challenge related to topographic analysis is that it does not take into account environmental variables such as area, maximum clay thickness, maximum elevation, shape and maximum Litorina water depth. The most interesting topographic class, narrow depressions, was thus further analysed to define which variables are associated with each other and certain locations. According to the results, large deep canyons are located in the central and southern parts of Espoo. The Suurpelto clay basin is one example of such depressions. Another type of narrow depressions was identified in the low-lying southern parts of Espoo, with a slightly thinner clay layer on average and a more rounded structure. Both types have deposited in the Litorina deep water. In addition, one type is only located in the north, where depressions occur at a high elevation and with quite thick layers of clay. These are related to bedrock topographic faults and weakness zones, which dominate the landscape in the north. Although there is some variation within narrow depressions, the variation is as expected and can be explained by general geological evolution. The classification will become increasingly accurate with more detailed preliminary information. Moreover, a study of bottom currents that prevailed during sediment deposition as well as sediment erosion and re-deposition, as has been reported by Nuorteva $\&$
Kankaanpää (2016) in the Archipelago sea, could provide additional information on the deposition environment but was not considered here.

\section{Conclusion}

Various challenges in land use and construction design related to the behaviour of post-glacial finegrained sediments are well known in Finland and in other Nordic countries. This study presents a novel approach to identify areas prone to these challenges. The Espoo area was classified into zones and structures according to the paleotopography after deglaciation and during the Litorina transgression. Topographic analysis and classification combined with selected environmental variables revealed different deposition environments for fine-grained sediments. For construction purposes, the most challenging environments were identified to be deep sheltered canyons that developed during the Litorina transgression. These are mainly located in the central and southern parts of Espoo, where land use is generally most active. Some notable finegrained deposits also occur in the northern parts of Espoo. Topographic analysis and classification can be considered a suitable approach to obtain essential information related to fine-grained sediment deposition environments on a regional scale and can help to optimize detailed site-specific ground investigations. The presented methodology can readily be extended to other coastal cities with finegrained sediments.

\section{Acknowledgements}

This study was funded by the Geological Survey of Finland and the K.H. Renlund Foundation. The source data used in the analyses were produced by the City of Espoo. Monica Löfman is thanked for valuable comments on the manuscript. Professor Jussi Leveinen and an anonymous reviewer provided valuable comments that improved the content of the manuscript. 


\section{References}

Åberg, S., 2013. Litorinameren ylin ranta Suomessa. Master's thesis, University of Helsinki, Faculty of Science, Department of Geosciences and Geography, 79 s (in Finnish).

Ancient shorelines. Geological Survey of Finland, HAKKU service. Available at https://hakku.gtk.fi/en/locations/search

Andrén, E., Andrén, T. \& Sohlenius, G., 2000. The Holocene history of the southwestern Baltic Sea as reflected in a sediment core from the Bornholm Basin. Boreas 29, 233-250.

Bjerrum, L., 1967. Engineering geology of normally consolidated marine clays as related to settlements of buildings. Geotechnique, 17, 83-119.

Björck, S., 1995. A review of the history of the Baltic Sea, 13.08.0 ka BP. Quaternary International 27, 19-40.

Boman, A., Astrom, M. \& Fröjdö, S., 2008. Sulfur dynamics in boreal acid sulfate soils rich in metastable iron sulfideThe role of artificial drainage. Chemical Geology 255, 6877. https:// doi:10.1016/j.chemgeo.2008.06.006

Boman, A., Fröjdö, S., Backlund, K. \& Åström, M. E., 2010. Impact of isostatic land uplift and artificial drainage on oxidation of brackish-water sediments rich in metastable iron sulfide. Geochimica et Cosmochimica Acta 74, 1268-1281. https://doi:10.1016/j.gca.2009.11.026

City of Espoo. Espoon kaavoitusohjelma 2018-2021. Available at https://www.espoo.fi/materiaalit/asuminen_ja_ ymparisto/verkkolehti/kaavoitusohjelma-2018/html5/ index.html?page $=1 \&$ noflash

Clay areas and depths 1:10000. Geological Survey of Finland, HAKKU service. Available at https://hakku.gtk.fi/fi/locations/search?location_id=197

Duxbury, A. B., Duxbury, A. C. \& Sverdrup, K.A. 2002. Fundamentals of Oceanography. McGraw Hill, New York, 344 p.

Gardemeister, R., 1975. On engineering-geological properties of fine-grained sediments in Finland. Technical Research Centre of Finland, Building Technology and Community Development, Helsinki, Publications 9, 91 p.

Ellonen, M. \& Taipale, T., 2019. Sulfaattimaatutkimukset Kallvikin Lambrobäckenin alueella. Research report, City of Espoo, 7 p (in Finnish).

Erdey-Heydorn, M. D., 2008. An ArcGIS Seabed Characterization Toolbox Developed for Investigating Benthic Habitats. Marine Geodesy 31, 318-358. https://doi: 10.1080/01490410802466819

Haavisto, M. \& Kukkonen, E., 1975. Quaternary deposits in the Helsinki map-sheet area including sea bottom. Maaperäkartan selitykset, 2034 Helsinki. Suomen geologinen kartta, 1:100000. Geological Survey of Finland, $20 \mathrm{p}$.

Helenelund, K. V., 1977. Methods for reducing undrained shear strength of soft clay. Report No 3, Swedish Geotechnical Institute.

Helsinki-Uusimaa Regional Council, 2019. Uusimaa-kaava
2050, Selostus. Available at

https://www.uudenmaanliitto.fi/files/24117/

UUSIMAA-KAAVA_Selostus.pdf

Henriksson, M. \& Myllyvirta, T., 2006. Suomen rannikkoalueen luokittelu rehevöitymisriskin perusteella. Itä-Uudenmaan ja Porvoonjoen vesien- ja ilmansuojeluyhdistys r.y (in Finnish).

Hutchinson, M. F., Xu, T. \& Stein, J. A., 2011. Recent Progress in the ANUDEM Elevation Gridding Procedure. In Hengel, T., Evans, I. S., Wilson, J. P. \& Gould. M. (ed.) Geomorphometry 2011. Redlands, California, USA. Available at

http://geomorphometry.org/HutchinsonXu2011

Hyvärinen, H., 1999. Shore displacement and Stone Age dwelling sites near Helsinki, southern coast of Finland. In Huurre, M. (ed.) Dig it all: papers dedicated to Ari Siiriäinen. Finnish Antiquarian Society, Archaeological Society of Finland, Helsinki, 79-89.

Härme, M., 1969. Geological map of Finland, Pre-Quaternary rocks, sheet 2043 Kerava. Geological Survey of Finland, Espoo.

Jokinen, S. A., Virtasalo, J. J., Jilbert, T., Kaiser, J., Dellwig, O., Arz, H. W., Hänninen, J., Arppe, L., Collander, M., \& Saarinen, T., 2018. A 1500-year multiproxy record of coastal hypoxia from the northern Baltic Sea indicates unprecedented deoxygenation over the 20th century. Biogeosciences, 15, 3975-4001. https://doi.org/10.5194/bg-15-3975-2018

Kaskela, A., 2017. Seabed landscapes of the Baltic Sea: Geological characterization of the seabed environment with spatial analysis techniques. Doctoral dissertation, Department of Geosciences and Geography, University of Helsinki, Geological Survey of Finland, Espoo, 41 p.

Kaskela, A., Kotilainen, A. T., Al-Hamdani, Z., Leth, J. \& Reker, J., 2012. Seabed geomorphic features in a glaciated shelf of the Baltic Sea. Estuarine, Coastal and Shelf Science 100, 150-161.

https://doi:10.1016/j.ecss.2012.01.008

Korkiala-Tanttu, L. \& Löfman, M., 2016. Luotettavuuden arviointi ja riskienhallinta geoteknisessä suunnittelussa. Liikenneviraston tutkimuksia ja selvityksiä 44/2016, 101 p (in Finnish).

Kosonen, E. \& Saresma, M., 2020. Savialueet ja syvyydet, loppuraportti. GTK work Report 37/2020, Geological Survey of Finland, Espoo, 13 p. (in Finnish). Available at https://hakku.gtk.fi/fi/reports/query_ db?utf8=\%E2\%9C\%93\&report_query\%5Bfield_ one $\% 5 \mathrm{D}=37 \% 2 \mathrm{~F} 2020 \%$ report_query $\% 5 \mathrm{Btarget}$ _one_ id $\% 5 \mathrm{D}=0 \&$ commit=Hae

Kosonen, E., Saresma, M., Ojala, A. E. K., Åberg, A., Åberg, S. \& Ikävalko, O., 2015. Hienorakeisten maalajien kerrosjärjestys ja ominaisuudet Helsingin Östersundomissa. GTK research Report 104/2015, Geological Survey of Finland, Espoo (in Finnish). 
Laitala, M., 1960. Geological map of Finland, Pre-Quaternary rocks, sheet 2032 Siuntio. Geological Survey of Finland, Espoo.

Laitala, M., 1967. Geological map of Finland, Pre-Quaternary rocks, sheet 2034 Helsinki. Geological Survey of Finland, Espoo.

Laitala, M., 1994. Geological map of Finland, Pre-Quaternary rocks, sheet 2041 Lohja. Geological Survey of Finland, Espoo.

Leverington, D. W., Teller, J. T. \& Mann, J. D., 2002. A GIS method for reconstruction of late Quaternary landscapes from isobase data and modern topography. Computers $\&$ Geosciences 28, 631-639. https://doi.org/10.1016/S0098-3004(01)00097-8

Lundblad, E. R., Wright, D. J., Miller, J., Larkin, E. M., Rinehart, R., Naar, D. F., Donahue, B. T., Anderson, S. M. \& Battista, T., 2006. A Benthic terrain classification scheme for American Samoa. Marine Geodesy 29, 89111. https://doi:10.1080/01490410600738021

Löfman, M., 2016. Perniön saven parametrien luotettavuuden ja saven eri ominaisuuksien välisten korrelaatioiden arviointi. Master's thesis, Aalto University School of Engineering, Espoo, $121 \mathrm{p}$ (in Finnish).

Löfman, M. \& Korkiala-Tanttu, L., 2019. Variability and Typical Value Distributions of Compressibility Properties of Fine-Grained Sediments in Finland. In Proceedings of the 7th International Symposium on Geotechnical Safety and Risk (ISGSR), 182-187.

https://doi:10.3850/978-981-11-2725-0 IS15-6-cd

Mataic, I., 2016. On structure and rate dependence of Perniö clay. Doctoral dissertation, Department of Civil Engineering, Aalto University, Espoo, 350 p.

Mäkiaho, J., 2009. Helsinki - Itämeren tytär: Paikkatietomenetelmät rannansiirtymistutkimuksessa. Terra 121, 3-17.

National Land Survey of Finland 1958a. Basic map 1:20000 Hämeenkylä. Map sheet 204301.

National Land Survey of Finland 1958b. Basic map 1:20000 Nuuksio. Map sheet 204110.

National Land Survey of Finland 1960. Basic map 1:20000 Tapiola. Map sheet 203403.

National Land Survey of Finland 1961. Basic map 1:20000 Espoo. Map sheet 203212.

Nuorteva, J., 1994. Topographically influenced sedimentation in Quaternary deposits - a detailed acoustic study from the western part of the Gulf of Finland. Doctoral dissertation, Faculty of Science of the University of Helsinki, Report of Investigation 122, Geological Survey of Finland, Espoo, 88 p.

Nuorteva, J. \& Kankaanpää, H., 2016. Relocation of soft mud deposits: An example from the Archipelago Sea, northern Baltic Sea. Marine Geology 380, 148-162. https://doi.org/10.1016/j.margeo.2016.08.002

Nuottimäki, K. \& Jarva, J., 2015. A qualitative approach for identifying areas prone to urban floods with the support of LiDAR. GFF 137,373-382.

https://doi.org/10.1080/11035897.2015.1055512
Ojala, A. E. K., 2007. Espoon Äijänpellon savikon stratigrafia ja geokemialliset piirteet. Open file Report P22.4/2007/26, Geological Survey of Finland, Espoo, 10 p (in Finnish).

Ojala, A. E. K., 2009. Hienorakeisten maalajien kerrosjärjestys: Perkkaa ja Mustalahti. Open file Report P 22.4/2009/58, Geological Survey of Finland, Espoo, 22 p (in Finnish).

Ojala, A. E. K., 2011. Construction suitability and 3D architecture of fine-grained sedimentary deposits in southern Finland - examples from Espoo. Geological Survey of Finland, Special Paper 49, 205-212.

Ojala, A. E. K., Ikävalko, O., Palmu, J.-P., Vanhala, H., Valjus, T., Suppala, I., Salminen, R., Lintinen, P. \& Huotari, T., 2007. Espoon Suurpellon alueen maaperän ominaispiirteet. Open file Report P22.4/2007/39, Geological Survey of Finland, Espoo, 51 p (in Finnish).

Ojala, A. E. K., Palmu, J.-P., Åberg, A., Åberg, S. ja Virkki, H., 2013. Development of an ancient shoreline database to reconstruct the Litorina Sea maximum extension and the highest shoreline of the Baltic Sea basin in Finland. Bulletin of the Geological Society of Finland 85, 127-144.

Ojala, A. E. K., Saresma, M., Virtasalo, J. J. \& HuotariHalkosaari, T., 2018. An allostratigraphic approach to subdivide fine-grained sediments for urban planning. Bulletin of Engineering Geology and the Environment 77, 879-892. https://doi.org/10.1007/s10064-016-0981-4

Pätsi, K., 2009. Suurpellon syvästabiloidun koepenkereen analysointi. Master's thesis, Faculty of Engineering and Architecture, Helsinki University of Technology, 103 p.

Quaternary superficial deposits (1:20000; 1:100 000). Geological Survey of Finland, HAKKU service. Available at https:/hakku.gtk.fi/en/locations/search

Repo, R., Valovirta, V. \& Rainio, H., 1970. Maaperäkartan selitys, Lehti 2032 Espoo, Suomen geologinen kartta. Explanation to Maps of Superficial Deposits, 1:100 000, Sheet 2032. Geologian tutkimuskeskus.

Rinne, H., Kaskela, A., Downie, A.-L., Tolvanen, H., von Numers, M. \& Mattila, J., 2014. Estuarine, Coastal and ShelfScience 138, 90-100.

http://dx.doi.org/10.1016/j.ecss.2013.12.025

Rohweder, J., Rogala, J. T., Johnson, B. L., Anderson, D., Clark, S., Chamberlin, F., Potter, D. \& Runyon, K., 2012. Application of Wind Fetch and Wave Models for Habitat Rehabilitation and Enhancement Projects 2012 Update. Contract report prepared for U.S. Army Corps of Engineers' Upper Mississippi River Restoration -Environmental Management Program. $52 \mathrm{~s}$.

Rosentau, A., Vassiljev, J., Saarse, L. \& Miidel, A., 2007. Palaeogeographic reconstruction of proglacial lakes in Estonia. Boreas 36, 211-221. https://doi.org/10.1111/j.1502-3885.2007.tb01193.x

Saresma, M., Ojala, A. E. K. \& Ikävalko, O., 2017. Hienorakeisten maalajien kerrosjärjestys ja ominaisuudet Helsingin Malmin lentokentän kaava-alueella. Research report GTK/957/03.02/2016, Geological Survey of Finland, $28 \mathrm{p}$ (in Finnish). 
Saresma, M., Kosonen, E., Kähkölä, N., Ojala, A. E. K., Auri, J. \& Huusko, A., 2020. Espoon sulfidisavien todennäköiset esiintymisalueet. Research report GTK/391/03.02/2019, Geological Survey of Finland, $32 \mathrm{p}$ (in Finnish).

Seppä, H., Tikkanen, M. \& Shemeikka, P., 2000. LateHolocene shore displacement of the Finnish south coast: diatom, litho- and chemostratigraphic evidence from three isolation basins. Boreas 29, 219-231. https://doi.org/10.1111/j.1502-3885.2000.tb00980.x

Statistics Finland, 2014. Väestö. Available at https://www.stat.fi/til/vaerak/2014/ vaerak_2014_2015-03-27_fi.pdf

Suikkanen, T., Lindroos, N., Autiola, M., Napari, M., Taipale, T., Laine, J., Forsman, J., Auri, J. \& Boman, A., 2018. Esiselvitys happamien sulfaattimaiden kartoitusmenetelmistä ja suosituksia toimenpiteiksi infrahankkeissa pääkaupunkiseudulla. Ramboll. Available at http://www.uusiomaarakentaminen.fi/sites/default/ files/Esiselvitys $\% 20$ happamien $\% 20$ sulfaattimaiden $\% 20$ kartoitusmenetelmist \%C3\%A4\%20ja\%20 suosituksia\%20toimenpiteiksi\%20infrahankkeissa\%20 p\%C3\%A4\%C3\%A4kaupunkiseudulla.pdf

Törnqvist, J. \& Laaksonen, R., 2008. Suurpellon sulfidisavien vaikutukset paalujen ja maanvastaisten betonilaattojen kestoikään ja teräsrakenteiden pysyvyyteen. Research report, City of Espoo, 23 p (in Finnish).

Valpola, S. ja Ojala, A. E. K., 2006. Post-glacial sedimentation rate and patterns on six lakes of the Kokemäenjoki upper watercourse, Finland. Boreal Environment Research 11, 195-211.

Virtanen, E. A., Norkko, A., Sandman, A. N. \& Viitasalo, M., 2019. Identifying areas prone to coastal hypoxia - the role of topography. Biogeosciences 16,3183-3195. https://doi.org/10.5194/bg-16-3183-2019

Virtasalo, J. J., Kohonen, T., Vuorinen, I., \& Huttula, T., 2005. Sea bottom anoxia in the Archipelago Sea, northern Baltic Sea-Implications for phosphorus remineralization at the sediment surface. Marine Geology 224, 103-122. https:// doi:10.1016/j.margeo.2005.07.010

Walbridge, S., Slocum, N., Pobuda, M. \& Wright, D. J., 2018. Unified Geomorphological Analysis Workflows with Benthic Terrain Modeler. Geosciences 8, 94. https://doi:10.3390/geosciences8030094

Weiss, A. D., 2001. Topographic position and landforms analysis. Poster presentation, ESRI Users Conference, San Diego, CA. 